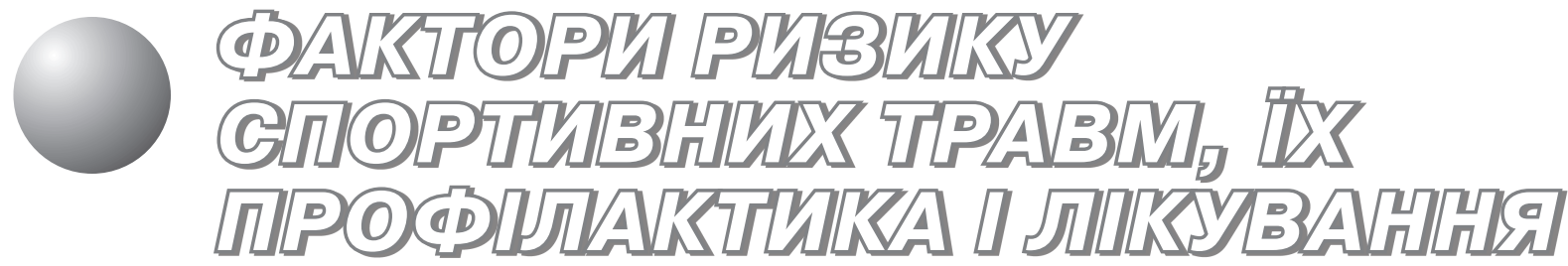

\section{Препарати, які модифікують структуру остеоартрозу: огляд наукової літератури}

\author{
В. М. Левенець', В. В. Манжалій
}

Центр спортивної травматології Національного університету фізичного виховання і спорту України, Київ, Україна ${ }^{1}$

Центр спортивної медицини, Київ, Україна²

\begin{abstract}
Резюме. Проведен анализ препаратов гиалуроновой кислоты, которые могут модифицировать течение остеоартроза у спортсменов. Высказано предположение, что препарат, в частности Синокром, влияет на патологические процессы, связанные с симптомами остеоартроза. Вискосапплементация завоевывает все большую популярность в качестве консервативного лечения у спортсменов. В случае остеоартроза у спортсменов выявлено уменьшение концентрации молекул гиалуроновой кислоты и снижение вязкости синовиальной жидкости. Вискосапплементация может стимулировать производство эндогенной гиалуроновой кислоты, которая положительно влияет на суставной хрящ путем эндопротекторного механизма. Это особенно важно для спортсменов на фоне постоянных больших нагрузок и возможности ежегодных повторений без побочных действий.
\end{abstract}

Ключевые слова: остеоартроз, вискосапплементация, футбол.

\begin{abstract}
Hyaluronic acid preparations, which may modify the course of osteoarthrosis in athletes, have been analyzed. It has been suggested that Synokrom preparation in particular, influences pathological processes, associated with osteoartrossi symptoms. Viscosupplementation has become a popular method of conservative treatment of athletes. Osteoartrosis in athletes leads to decrease of concentration of hyaluronic acid molecules and lower viscosity of synovial fluid. Viscosupplementation may stimulate production of endogeneous hyaluronic acid, which positively affects articular cartilage by endoprotective mechanism. It is especially important for athletes in the face of continuous high loads and possibility of annual repetition of treatment without side effects.
\end{abstract}

Key words: osteoarthrosis, viscosupplementation, football.

Постановка проблеми. Останніми роками широко застосовують неоперативне лікування остеоартрозу (ОА) колінного суглоба шляхом внутрішньосуглобового введення препаратів гіалуронової кислоти (ГК), яка знижує больові відчуття і покращує функцію суглоба. 3 кожним роком збільшується кількість доказів ефективності цього методу лікування ОА $[1,4,21,33]$.

Неоперативні методи лікування симптоматичного ОА включають фрізіотерапевтичні процедури, ЛФК, системну ензимотерапію, нестероїдні протизапальні препарати (НПЗП), але до останніх необхідно ставитись дуже обережно, коли йдеться про спортсменів, зокрема футболістів [1].
Стосовно внутрішньосуглобових ін'єкцій ГК пружнов'язкого мукополісахаридного компонента синовіальної рідини - то останні стали найбільш популярною складовою неоперативного методу лікування ОА у фрутболістів [3].

Молекули ГК разом із колагеном II типу входять до складу протеогліканів, $\epsilon$ важливим компонентом матриксу хряща і суглобової рідини і виконують люмбрикантні і амортизаційні фрункції. У випадках ОА визначається зменшення концентрації молекул ГК та зниження в'язкості синовіальної рідини. Введення екзогенної ГК у вигляді препаратів замісної терапії пропонували як структурно-модифікуючий засіб стосовно гіалінового хряща $[5,6,13,19,22,23,34]$. 
У дорослої людини в здоровому колінному суглобі міститься близько 2 мл синовіальної рідини 3 концентрацією ГК приблизно 2,5-4,0 мг $\cdot$ мл $^{-1}$. Ця ендогенна ГК, яку виробляють синовіоцити типу «В» і фрібробласти синовіальної мембрани, має молекулярну масу $(5-7) 10^{6}$ Да $[10$, 18, 35].

В ураженому ОА суглобі молекулярна маса і концентрація ГК $€$ зменшеними приблизно на $40 \%$, що значно обмежує їх роль у підтримці нормальної біомеханіки суглоба [7, 35].

У зв'язку з цим метою віскосапплементації $\epsilon$ поповнення втрати ГК i, можливо, стимулювання виробництва ендогенної ГК у суглобі [29]. I хоча до сьогодні механізм дії препаратів ГК остаточно не з'ясований, результати досліджень свідчать, що ГК зменшує больові відчуття, має протизапальний i, можливо, хондропротекторний ефект на суглобовий хрящ і синовіальну оболонку і рідину.

Згідно 3 існуючими теоріями ефеективність високомолекулярних препаратів можна пояснити протекторним діям сіновіоцитів за рахунок зміни реології синовіальної рідини, розпорошенням механічних ударів і попередженням морфологічних змін структури клітин [4, 8, 17, 25].

При введенні в суглоб, уражений ОА, ГК за короткий проміжок часу поліпшує змазку суглоба $[15,20]$. Крім того, віскосапплементація може забезпечити протизапальний ефрект, а впливаючи на функцію лейкоцитів, зменшити концентрацію протизапальних медіаторів, таких, як фрібронектин і простагладини [24, 26, 32]. У проведених експериментальних дослідженнях на тваринах визначено безпосередні аналгетичні і, головне, хондропротекторні властивості внутрішньосуглобових ін'єкцій $[11,28]$.

Визначення кандидатів на проведення віскосапплементації має досить велике значення для пересічних громадян. Цілком очевидно, що не слід вводити ГК пацієнтам, якщо вони не скаржились на значний біль, обумовлений ОА суглоба, або якщо можна призначити інші консервативні методи лікування, такі, як нестероїдні протизапальні препарати, фрізіотерапію, ЛФК.

Слід відзначити, що спортсмени рідко використовують НПЗП у зв'язку з можливими ускладненнями. Не можна не згадати про визначення часу виконання віскосапплементації у зв'язку з тим, що цей фракт забезпечує максимальне полегшення симптомів.

Результати численних досліджень вказують, що тяжкість ОА добре корелює з реакцією пацієнта і може бути важливим фактором у визначенні часу виконання цих ін'єкцій протягом перебігу захворювання.
За нашими даними, внутрішньосуглобові ін'єкції дають найбільший ефект на ранньому етапі, тобто стадії передартроза.

Відомо, що результати внутрішньосуглобових ін'єкцій ГК для неоперативного лікування ОА колінного суглоба $\epsilon$ позитивними, хоча ступінь їх впливу неоднакова [4, 13, 24, 35]. У дослідженні, яке виконали N. Bellamy зі співавт. [9], одержано дані про те, що внутрішньосуглобові ін'єкції ГК $\epsilon$ ефрективним засобом лікування ОА колінного суглоба. Відмічено зменшення рівня болю і очевидне покращення фрункції через 5-19 тиж. після останньої ін'єкції.

Цікавим $€$ дослідження, в якому через 6 міс. після ін'єкцій ГК виявили помітне зменшення больових відчуттів і покращення функціонального стану суглоба порівняно з плацебо [6].

Порівняння ефрективності застосування внутрішньосуглобових ін'єкцій, зокрема Гіалгану і кортикостероїдів, засвідчило позитивний протибольовий ефект останніх, але це відбувалося лише протягом двох тижнів. Водночас зменшення ступеня больових відчуттів та покращення функціонального стану суглоба відмічалися протягом 3-6 тиж. після закінчення лікування і були більш тривалими після введення Гіалгану.

Клінічні дослідження показали добру переносимість віскосапплементації [5]. У той же час не можна не відмітити незначні побічні дії, які відзначені у 3-20\% пацієнтів. Ці ускладнення визначено в кінці минулого сторіччя, і на думку окремих авторів, вони були пов'язані з технічними умовами виробництва [12]. Останніми роками технологію виробництва препаратів, які містять ГК, наприклад SYNOCROM ${ }^{\circledR}$, значно вдосконалено, що дозволило практично ліквідувати побічні ефекти. Проте окремі автори до цього часу наводять приклади деяких ускладнень - запальна реакція на місці введення ГК $[14,16]$, набряк суглоба [16]. Точні причини виникнення зазначених ускладнень не зовсім ясні, а ті, які автори наводять, не $\epsilon$ коректними.

Певний час у літературі існувала точка зору, згідно з якою ГК може модифрікувати захворювання ОА колінного суглоба. I хоча період їі дії коливається від 3 до 10 діб, залежно від виду препарату, дослідники звернули увагу на те, що тривалість впливу введеної ГК суттєво перебільшує період напіввиведення з суглоба [14]. Пізніше було висловлено припущення, що ГК може також впливати на патологічні фрактори, що пов'язані з симптомами ОА [9]. Попередня стаття підтвердила гіпотезу, згідно з якою екзогенна ГК знижує ступінь дегенерації суглобового хряща і сприяє його заживленню. 
На початку XXI ст. у ряді клінічних досліджень було одержано докази потенціальних можливостей ГК модифікувати ОА. Так, у дослідженні А. Migliore зі співавт. [24] проведено клінічну роботу, в якій було оцінено результати введення Гіалгану в тазостегновий суглоб, де було виявлено ОА. I хоча артроскопічно і рентгенологічно через 9 міс. погіршення виявлено в обох групах (Гіалган та контрольна група), менш вираженими були явища у групі, котра отримувала Гіалган [24].

В іншому дослідженні, через 6 міс. після трьох ін'єкцій Гіалгану з високою молекулярною вагою, концентрація препарату була приблизно вище, ніж перед початком дослідження. Це свідчить про те, що ін'єкції ГК можуть стимулювати ендогенну ГК i, таким чином, змінювати прогресування захворювання [28].

Відомо, що деякі автори рекомендують після артроскопії вводити препарати ГК, мотивуючи цю процедуру тим, що під час артроскопії рідина, яку застосовують з метою промивання, разом із чужорідними речовинами і цитокинами вимиває синовіальну рідину і змазувальний шар, що покриває суглобову поверхню [27]. Ця процедура може негативно вплинути на метаболізм хондроцитів, тому автори припустили, що внутрішньосуглобові ін'єкції ГК можуть позитивно впливати на післяопераційний стан і покращувати ефективність лікування та спроможність відновлення змазувального та захисного шарів [20].

За даними окремих авторів, ГК може позитивно впливати шляхом хондропротекторного механізму на суглобовий хрящ, обмежуючи негативну дію, яка пов'язана 3 крайовим тиском при навантаженні кінцівки. Так, наприклад, G. Tytherleigh-Strong зі співавт. визнали, що ін'єкції ГК забезпечували інтеграцію

\section{Література}

1. ЛеВенець В.М. Спортивна травматологія / В. М. Левенець, Я. В. Лінько. - К.: Олімп. л-ра, 2008. - 245 с.

2. ЛеВенеи В. Н. Особенности диагностики и комплексной терапии спортсменов в стадии предартроза / В. Н. Левенец, М. М. Риган, И. М. Тютюнник // Спорт. мед. 2013. - № 1 - С. 33-47.

3. КоВаленко В. Н. Остеоартроз: практическое руководство / В. Н. Коваленко, О. П. Борткевич. - К.: Морион, 2003. - 147 c.

4. Adams M. E. Hypertrophic repair of canine articular car-tilage in osteoarthritis after anterior cruciate ligament transaction / M. E. Adams, K. D. Brandt // Rheumat. 1991. - Vol. 18(3).- P. 428-435.

5. Altman R. D. Double-blind randomired trial of intraarticular injection of sodium hyalunane (Hyalgan) for the treatment of chrome shoulder pain / R. D. Altman, R. Mos- імплантованих остеохондральних імплантатів 3 обмежувальною тканиною [33].

У відкритому пілотному дослідженні S. Clarke зі співавт. виявлено, що ін'єкції ГК суттєво знижують загальні больові відчуття у ділянці колінного суглоба, які відчувались перед початком лікування, що відрізняє результати цього дослідження від інших, оскільки покращення зберігалося упродовж 12 міс. [4].

Останнім часом у літературі актуальним стало питання визначення часу та кількості введення ГК. Управління з контролю за харчовими продуктами і лікарськими засобами США схвалило повторні курси внутрішньосуглобових ін'єкцій ГК [10].

Нині поширеними $€$ клінічні і експериментальні дослідження, що спрямовані на визначення механізму дії введеної ГК, зокрема на метаболізм хондроцитів, і його впливу на патогенез OA. Так, Echigo R. зі співавт. [16] встановили, що ін'єкції ГК подавляли апоптоз хондроцитів порівняно з контрольними зразками. Роком пізніше у експериментальній роботі L. Diaz-Gallego зі співавт. [14] було доведено, що хондропротекторна дія ГК $€$ вторинною щодо інгібування виробництва оксиду азоту, медіатора, який, можливо, сприяє дегенерації хряща та некрозу хондроцитів.

Висновки. Внутрішньосуглобові ін'єкції ГК набувають все більшої популярності як неоперативний метод лікування пацієнтів, хворих на ОА [35]. Особливо це важливо для спортсменів, зокрема фрутболістів, у зв'язку з постійно високими, іноді позамежними, навантаженнями, частими хронічними мікротравмами, що повторюються. Крім того, цей метод дає можливість виконувати його не виключаючи спортсмена від тренувального і змагального режимів, а головне, знижує ризик ОА і віддаляє його розвиток [2].

\section{References}

1. Levenets V. M. Sports traumatology / V. M. Levenets, Y. V. Linko. - Kyiv: Olimpiiska literatura, 2008. - 245 p.

2. Levenets V. N. Peculiarities of diagnosis and complex therapy of athletes at pre-arthrosis stage / V. N. Levenets, M. M. Rigan, I. M. Tyutyunnik // Sport. med. - 2013. - N1 P. 33-47.

3. Kovalenko V. N. Osteoarthrosis: practical guide / V. N. Kovalenko, O. P. Bortkevich. - Kiev: Morion, 2003. $147 \mathrm{p}$.

4. Adams M. E. Hypertrophic repair of canine articular cartilage in osteoarthritis after anterior cruciate ligament transaction / M. E. Adams, K. D. Brandt // Rheumat. 1991. - Vol. 18(3).- P. 428-435.

5. Altman R. D. Double-blind randomired trial of intraarticular injection of sodium hyalunane (Hyalgan) for the treatment of chrome shoulder pain / R. D. Altman, 
kowitz, S. lacobs et. al. // Arthritis Rheumatal. - 2005. Vol. $5 / 2$ (suppe I). - P. 54.

6. Altman R. D. Hiffracy of intra-articular hyaluronan (HyaIgan) in a double-blind study for osteoarthritis of the ankle / R. D. Altman, M. M. Cohem, R. lollstrom et. al. // Osteoarthritis Cartilage. - 2006. - Vol. 14 (suppe B). - S. 170.

7. Bagga H. Longfern effects of osteoarthritis / H. Bagga, D. Burkhardt, P. Sambrook et al. //Clin. Exp. Rheumat. 2005. - Vol. 23(5). - P. 711-716.

8. Balazs $F$. A. Viscosupplementation: a new concept in the treatment of osteoarthritis / F. A. Balazs, I. L. Denlinger // I. Rheumat. Suppl. - 1993. - Vol. 39. - P. 3-9.

9. Bellamy N. Wiscocapplementation for thetreatmen of osteoarthritis of the knee / N. Bellamy et al. //Cochrane Data-base Syst. Rev. - 2006. - CD005321.

10. Brockmeier S. F. Viscosupplemention therapy for osteoarthritis / S. F. Brock-meir, B. S. Shaffer // Sports Med. Arthroscop - 2006. - Vol. 14(3). - P. 155-162.

11. Bu/stra S. K. The effecting vitro of irrigating solutions on intact rat articular cartilage /S. K. Bulstra. R Kuijer, P. Eerdmans et al. // I. Bone loint Surg. Br. - 1994. Vol. 76(3). - P. 468-470.

12. Clark S. Intraarticular hylan G-F 20 (Synvisc) in the management of patellofemoral osteoarthritis of the knee / S. Clark, V. Lock, I. Dunddy et al. / / POAK-Knee. - 2005. Vol. 12(1). - P. 57-62.

13. Dahlberg L. Intraarticular injections of hyaluronan in patients with cartilage abnormalities and knee pain: one year double-blind, placebo-controlled study / L. Dahlberg, L. S. Lohmander, L. Ryd // Arthrits Rheumat. - 1994. Vol. 37(4).- P. 521-528.

14. Diaz-Gallego L. Apopto-sisand nitric oxide in an experimental in odel of osteoarthritis in rabbit after hyaluronic acid treatment / L. Diaz-Gallego et al. // I. Orthop. Res. - 2006. - Vol. 23(6). - P. 1370-1376.

15. Divine I. G. Viscocupplementation for knee osteoarthritis: a systematic review / I. G. Divine, B. T. Zazulak, T. E. Hewett / / Clin. Orthop. Relat Res. - 2007. - Vol. 455. P. 113-122.

16. Echigo $R$. Suppressive effect of hyaluronan on chondrocyte apoptosisin experimentally induced acute osteoarthritis indogs / R. Echigo, M. Mochizuki, R. Nisihmura et al. // Med. Sci. - 2005. - Vol. 68(8). - P. 899-902.

17. Ghosh $P$. The role of hyaluronic acid (hyaluronans in health and disease: interactions with cells, cartilage and components of synovial fluid / P. Ghosh // Clin. Exp. Rheumat. - 1994. - Vol. 12(1). - P. 75-82.

18. Goldberg V. M. Psendoseptic reactions to hylan viscocupplementation: diagnosis and treatment / V. M. Goldberg, R. D. Coutts // Clin Orthop. Relares. - 2004. - Vol. 419. P. $130-137$.

19. Goldberg V. M. Hyaluronans in the treatment of osteoarthritis of the knee: evidence for disease-modifying activity / V. M. Goldberg, I. A. Buckwalter // Osteoarthritis Cartilage. - 2005. - Vol. 13(3). - P. 216-224.

20. Hempfling $H$. Intra-articular hyaluronic acid after knee arthroscopy: a two-year study / H. Hempfling / / Knee Surg Sports Trdumatol Arthrosc. - 2007. - Vol. 15(5). - P. 537546.

21. Hootman J. M. Projections of Us prevalence of arthritis and associated activity limitations / J. M. Hootman, C. G. Helmick // Arthritis Rheumat. - 2006. - Vol. 54(1). P. 226-229.

22. Kirwan I. Is there a place for intra-articular hyalunate in osteoarthritis of the knee? / I. Kirwan // The knee. 2001. - Vol. 8. - P. 93-101.
R. Moskowitz, S. lacobs et. al. // Arthritis Rheumatal. 2005. Vol. 5/2 (suppl. I). - P. 54.

6. Altman $R$. D. Efficacy of intra-articular hyaluronan (Hyalgan) in a double-blind study for osteoarthritis of the ankle / R. D. Altman, M. M. Cohem, R. lollstrom et. al. // Osteoarthritis Cartilage. -2006. - V. 14 (suppl. B). - S. 170.

7. Bagga H. Long-term effects of osteoarthritis / H. Bagga, D. Burkhardt, P. Sambrook et al. // Clin. Exp. Rheumat. - 2005. - V. 23(5). - P. 711-716.

8. Balazs F. A. Viscosupplementation: a new concept in the treatment of osteoarthritis /F. A. Balazs, I. L. Denlinger // I. Rheumat. Suppl. - 1993. - Vol. 39. - P. 3-9.

9. Bellamy N. Viscosupplementation for the treatment of osteoarthritis of the knee / N. Bellamy et al//Cochrane Database Syst. Rev. - 2006. - CD005321.

10. Brockmeier S. F. Visco-supplemention therapy for osteoarthritis / S. F. Brockmeir, B. S. Shaffer // Sports Med. Arthroscop - 2006. - Vol. 14(3). - P. 155-162.

11. Bulstra S. K. The effecting vitro of irrigating solutions on intact rat articular cartilage /S. K. Bulstra. R Kuijer, P. Eerdmans et al. // I. Bone loint Surg. Br. - 1994. Vol. 76(3). - P. 468-470.

12. Clark S. Intraarticular hylan G-F 20 (Synvisc) in the management of patellofemoral osteoarthritis of the knee / S. Clark, V. Lock, I. Dunddy et al. // POAK-Knee. - 2005. Vol. 12(1). - P. 57-62.

13. Dahlberg L. Intraarticular injections of hyaluronan in patients with cartilage abnormalities and knee pain: one year double-blind, placebo-controlled study / L. Dahlberg, L. S. Lohmander, L. Ryd // Arthrits Rheumat. -1994. Vol. 37(4).- P. 521-528.

14. Diaz-Gallego L. Apopto-sisand nitric oxide in an experimental in model of osteoarthritis in rabbit after hyaluronic acid treatment / L.Diaz-Gallego et al. / / I. Orthop. Res. - 2006. - Vol. 23(6). - P. 1370-1376.

15. Divine I. G. Viscosupplementation for knee osteoarthritis: a systematic review / I. G. Divine, B. T. Zazulak, T. E. Hewett / / Clin. Orthop. Relat Res. - 2007. - Vol. 455. P. $113-122$.

16. Echigo R. Suppressive effect of hyaluronan on chondrocyte apoptosis in experimentally induced acute osteoarthritis in dogs / R. Echigo, M. Mochizuki, R. Nisihmura et al. // Med. Sci. - 2005. - Vol. 68(8). - P. 899-902.

17. Ghosh $P$. The role of hyaluronic acid (hyaluronans in health and disease: interactions with cells, cartilage and components of synovial fluid / P. Ghosh // Clin. Exp. Rheumat. - 1994. - Vol. 12(1). - P. 75-82.

18. Goldberg V. M. Pseudoseptic reactions to hylan viscosupplementation: diagnosis and treatment / V. M. Goldberg, R. D. Coutts // Clin Orthop. Relares. - 2004. - Vol. 419. P. $130-137$.

19. Goldberg V. M. Hyaluronans in the treatment of osteoarthritis of the knee: evidence for disease-modifying activity / V. M. Goldberg, I. A. Buckwalter // Osteoarthritis Cartilage. - 2005. - Vol. 13(3). - P. 216-224.

20. Hempfling $H$. Intra-articular hyaluronic acid after knee arthroscopy: a two-year study / H. Hempfling // Knee Surg Sports Trdumatol Arthrosc. - 2007. - Vol. 15(5). - P. 537546.

21. Hootman J. M. Projections of prevalence of arthritis and associated activity limitations / J. M. Hootman, C. G. Helmick // Arthritis Rheumat. - 2006. - Vol. 54(1). P. 226-229.

22. Kirwan $I$. Is there a place for intra-articular hyalunate in osteoarthritis of the knee? / I. Kirwan // The knee. 2001. - Vol. 8. - P. 93-101. 
23. Kotevoglu N. A prospective-randomized controlled clinical trial comparing the effecialy of different molecular weight hyaluronan solutions / N. A. Kotevoglu et al. // Rheumat Int. - 2006. - Vol. 26. - P. 325-330.

24. Migliore $A$. The sympionatic effents of intra-articular administration of hylan G-F 20 on osteoarthritis of the hip: clinical data of 6 months follow-up / A. Migliore, S. Tormenta, L. Martin et al. / /Clin Rheumat. - 2006. - Vol. 25(3). P. 389-393.

25. Miyakoshi N. Effects of intra-articular administration of basic fibroblast growth factor with hialuronic acid on osteochondral defects of the knee in rabbits / N. Miyakoshi et al. / / Arch. Orthop. Trauma Surg. - 2005. - Vol. 125(10). P. 683-692.

26. Moskowitz R. W. An overview of treatment options for persistent shoulder pain /R. W. Moskowitz, T. A. Blaine//Am. I. Orthop. - 2005. - Vol. 34(12 suppe). - P. 10-15.

27. Pourbagher M. A. Accuracy and outcome of sonographically guided intra-articular sodium hyaluronate injection in patients with osteoarthritis of the hip / M. A. Pourbagher et al.// I. Ultra Sound Med. - 2005. Vol. 24 (10). - P. 1391-1395.

28. Punzi $L$. The influence of intra-articular hyaluronic acid on P6E2 and c AMP of synovial fluid / L. Punzi et al. // I. Rheumatol. - 1995. - Vol. 22(7). - P. 1311-1314.

29. Santangelo K. S. Effects of hyaluronan treatment on lopopobysaccharide-challenged fibroblast-like synovial cells / K. S. Santangelo, L. Amanda Johnson, A. S. Ruppert et al.// Arthritis Research Therapy. - 2007. - Vol. 9, N1.

30. Stewart W. $F$. Lost productive time and cost due to common pain conditions in the US workforee / Stewart W. F., J. A. Ricci, E. Chee et al. // JAMA. - 2003. Vol. 290(18). - P. 2443-2454.

31. Strauss E. I. Hyaluronic Acid Viscosupplementation and osteoarthritis. Current Uses and Future Direction / E. I. Strauss, I. A. Hart, M. D. Miller et al.// Am. I. Sport Med. - 2009. - P. 48-61.

32. Tikiz C. Comparison of the efficacy of lower and higher molecular weight viscosapplementation in the treatment of hip osteoarthritis / C.Tikiz, A. Sener et al. // Clin. Rheumat. 2005. - Vol. 24(3). - P. 244-250.

33. Tytherleigh-Strong G. Intra-articular hyaluronan fallowing autogenous osteochondral grafting of the knee / G. Tytherleigh-Strong, M. Hurtig, A. Miniau // Arthros-copy. 2005. - Vol. 21(8). - P. 999-1005.

34. Vagishita $K$. The effect of hyaluronan on tendon healing in rabbits / K. Vagichita et al. / / Arthroscopy. 2005. - Vol. 21(11). - P. 1330-1336.

35. Watterson I. R. Viscosupplementation: therapeutic 35. mechanisms and clinical potential in osteoarthritis of the knee / I. R. Watterson, M. Esdail // J. Am. Acad Orhop. Surg. 2000. - Vol. 8 (5). - P. 277-284.

debn77@ukr.net
23. Kotevoglu N. A prospective-randomized controlled clinical trial comparing the efficiency of different molecular weight hyaluronan solutions / N. A. Kotevoglu et al. // Rheumat Int. - 2006. - Vol. 26. - P. 325-330.

24. Migliore $A$. The sympionatic effents of intra-articular administration of hylan G-F 20 on osteoarthritis of the hip: clinical data of 6 months follow-up / A. Migliore, S. Tormenta, L. Martin et al. / /Clin Rheumat. - 2006. - Vol. 25(3). P. 389-393.

25. Miyakoshi N. Effects of intra-articular administration of basic fibroblast growth factor with hyaluronic acid on osteochondral defects of the knee in rabbits / N. Miyakoshi et al. / Arch. Orthop. Trauma Surg. - 2005. - Vol. 125(10). P. 683-692.

26. Moskowitz R. W. An overview of treatment options for persistent shoulder pain /R. W. Moskowitz, T. A. Blaine// Am. I. Orthop. - 2005. - Vol. 34(12 suppl). - P. 10-15.

27. Pourbagher M. A. Accuracy and outcome of sonographically guided intra-articular sodium hyaluronate injection in patients with osteoarthritis of the hip / M. A Pourbagher et al.// I. Ultra Sound Med. - 2005. - Vol. 24 (10). - P. 13911395.

28. Punzi L. The influence of intra-articular hyaluronic acid on P6E2 and C AMP of synovial fluid / L. Punzi et al. // I. Rheumatol. - 1995. - Vol. 22(7). - P. 1311-1314.

29. Santangelo K. S. Effects of hyaluronan treatment on lopopobysaccharide-challenged fibroblast-like synovial cells / K. S. Santangelo, L. Amanda Johnson, A. S. Ruppert et al.// Arthritis Research Therapy. - 2007. - Vol. 9, N1.

30. Stewart W. F. Lost productive time and cost due to common pain conditions in the US workforce / W. F. Stewart, Ricci J. A., Chee E. et al. // JAMA. - 2003. - Vol. 290(18). P. 2443-2454.

31. Strauss E. I. Hyaluronic Acid Viscosupplementation and osteoarthritis. Current Uses and Future Direction / E. I. Strauss, I. A. Hart, M. D. Miller et al.// Am. I. Sport Med. - 2009. - P. 48-61.

32. Tikiz C. Comparison of the efficacy of lower and higher molecular weight viscosupplementation in the treatment of hip osteoarthritis / C.Tikiz, A. Sener et al. // Clin. Rheumat. 2005. - Vol. 24(3). - P. 244-250.

33. Tytherleigh-Strong $G$. Intra-articular hyaluronan following autogenous osteochondral grafting of the knee / G. Tytherleigh-Strong, M. Hurtig, A. Miniau // Arthroscopy. 2005. - Vol. 21(8). - P. 999-1005.

34. Vagishita K. The effect of hyaluronan on tendon healing in rabbits / K. Vagishita et al. // Arthroscopy. 2005. - Vol. 21(11). - P. 1330-1336.

35. Watterson I. R. Viscosupplementation: therapeutic 35. mechanisms and clinical potential in osteoarthritis of the knee / I. R. Watterson, M. Esdail // J. Am. Acad Orhop. Surg. 2000. - Vol. 8 (5). - P. 277-284.

Надійшла 02.02.2014 